\title{
FAKTOR-FAKTOR YANG MEMPENGARUHI KEPUASAN KERJA KARYAWAN PADA PT CITRA CROCOTAMA INTERNATIONAL DI JAKARTA
}

\author{
Steven Saputra dan Kurniati W. Andani
}

Program Studi Manajemen, Fakultas Ekonomi dan Bisnis, Universitas Tarumanagara Jakarta Email: stevensaputra313@gmail.com

\begin{abstract}
This study aims to analyze the effect of the Work Environment, Motivation and Organizational Commitment on Employee Job Satisfaction at PT Citra Crocotama International in Jakarta. This research was conducted using probability sampling method with a type of simple random sampling. The researcher distributed questionnaires to 77 employees of PT Citra Crocotama International. Data analysis using Smart PLS analysis. The results of the analysis concluded that the work environment, motivation and organizational commitment had a significant effect on job satisfaction PT Citra Crocotama International in Jakarta.
\end{abstract}

Keywords: work environment, motivation, organizational commitmet and job satisfaction.

Abstrak: Penelitian ini bertujuan untuk menganalisis pengaruh Lingkungan Kerja, Motivasi Dan Komitmen Organisasi Terhadap Kepuasan Kerja Karyawan Pada PT Citra Crocotama International di Jakarta. Penelitian ini dilakukan dengan metode probability sampling dengan jenis simple random sampling. Peneliti menyebarkan kuesioner kepada 77 karyawan PT Citra Crocotama International. Analisis data menggunakan analisis Smart PLS. Hasil analisis menyimpulkan bahwa lingkungan kerja, motivasi dan komitmen organisasi berpengaruh signifikan terhadap kepuasan kerja PT Citra Crocotama International di Jakarta.

Kata kunci: lingkungan kerja, motivasi, komitmen organisasi dan kepuasan kerja.

\section{LATAR BELAKANG}

Sumber daya manusia di perusahaan memiliki peranan yang penting dalam mencapai tujuan perusahaan. Sumber daya manusia melingkupi keseluruhan karyawan di dalam perusahaan yang terlibat dalam segala kegiatan perusahaan baik dari level yang paling bawah sampai level yang paling tinggi. Sumber daya manusia merupakan salah satu sumber daya yang ada dalam suatu perusahan disamping sumber daya yang lain, misalnya modal, material dan mesin Hal ini karena manusia yang mengelola sumber daya lainnya yang ada dalam perusahan, sehingga menjadi bermanfaat. Oleh karena itu, sumber daya manusia sangat penting dalam perusahaan. Sumber daya manusia seperti karyawan merupakan harta perusahaan yang terpenting. Perusahaan membutuhkan karyawan untuk kelangsungan kegiatan usaha dan pengembangan produksi. Hal ini dikarenakan, walaupun perencanaan perusahaan sudah sempurna, namun bila sumber daya manusianya tidak dapat menjalankan tugasnya dengan perasaan senang, maka perusahaan tidak akan mendapatkan hasil yang maksimal.

Banyak hal yang dilakukan perusahaan untuk memenuhi keinginan karyawan dengan tujuan untuk meningkatkan produktifitasnya dan juga menjaga kepuasan kerja karyawannya. Karyawan yang puas akan bekerja tanpa beban dan memberikan usaha lebih kepada 
pekerjaannya, serta setia kepada perusahaan dan pimpinannya. Perusahaan dapat kurang memperhatikan kebutuhan dan keinginan karyawannya, sehingga kepuasan kerja menurun. Ini pada akhirnya menimbulkan banyak masalah dalam pekerjaan seperti turunnya disiplin kerja karyawan, turn over karyawan yang tinggi serta menurunkan kinerja perusahaan secara drastis. Hal tersebut sangat merugikan perusahaan, dikarenakan perusahaan harus mengeluarkan bermacam biaya, misalnya pesangon, dan perekrutan karyawan baru yang menghabiskan banyak biaya. Menurut Timotius (2016:244) kepuasan kerja adalah keadaan menyenangkan yang dialami individu dalaam organisasi oleh berbagai hal yang menjadi penyebabnya.

Banyak faktor yang biasa mempengaruhi kepuasan kerja karyawan, dan saling berkaitan. Faktor yang mempengaruhi kepuasan kerja karyawan di antaranya adalah lingkungan kerja dan motivasi (Wuwungan, dkk 2017). Lingkungan kerja merupakan segala sesuatu yang ada di lingkungan pekerja yang dapat mempengaruhi dirinya dalam menjalankan tugas yang dibebankan. Lingkungan kerja tempat karyawan bekerja sangat penting di dalam meningkatkan kepuasan kerja karyawan. Dimana lingkungan kerja adalah kondisi-kondisi material dan psikologis yang ada dalam organisasi. Maka dari itu, organisasi harus menyediakan lingkungan kerja yang memadai seperti lingkungan fisik (tata ruang kantor yang nyaman, lingkungan yang bersih, pertukaran udara yang baik, warna, penerangan yang cukup maupun musik yang merdu), serta lingkungan non fisik (suasana kerja karyawan, kesejahteraan karyawan, hubungan antar sesama karyawan, hubungan antar karyawan dengan pimpinan, serta tempat ibadah). Lingkungan kerja yang baik dapat mendukung pelaksanaan kerja sehingga karyawan memiliki semangat bekerja dan meningkatkan kepuasan kerja karyawan. Penelitian Saputra dan Andri (2017) menyatakan bahwa lingkungan kerja berpengauh terhadap kepuasan kerja karyawan. Kemudian dalam penelitian Husni, dkk (2018) menyimpulkan bahwa lingkungan kerja juga mempengaruhi kepuasan kerja karyawan.

Selain lingkungan kerja, yang dapat meningkatkan kepuasan kerja adalah dengan pemberian motivasi yang tepat kepada para karyawan (Wuwungan, dkk 2017). Pada perusahaan pemberian motivasi untuk karyawan merupakan aspek penting dalam meningkatkan kepuasan kerja karyawan. Jika kepuasan kerja karyawan terpenuhi, bukan tidak mungkin maka kinerja yang dihasilkan karyawanpun akan maksimal. Menurut Darmadi (2018:125), motivasi merupakan dorongan dasar yang menggerakkan seseorang bertingkah laku. Dalam hal ini motivasi adalah serangkaian dorongan yang dirumuskan secara sengaja oleh perusahaan kepada karyawan agar mereka bersedia secara ikhlas melakukan perilaku tertentu yang berdampak kepada peningkatan kinerja dalam rangka pencapaian perusahaan yang telah di tetapkan sebelumnya. Motivasi merupakan penggerak dan pendorong individu untuk melaksanakan kegiatan guna mencapai suatu tujuan. Motivasi bisa datang dari dalam diri sendiri maupun dorongan orang lain. Dalam organisasi seorang pemimpin harus dapat memotivasi pegawai, seorang pemimpin harus dapat meningkatkan semangat dan gairah kerja, harus dapat meningkatkan prestasi kerja, harus mampu meminimalisir kesalahan yang mungkin terjadi, harus mampu meminimalisir konflik dalam organisasi serta harus mampu menciptakan produktivitas kerja dan meningkatkan kepuasan kerja (Darmadi, 2018:130). Jadi seorang pemimpin memiliki peranan yang cukup besar dalam memberikan motivasi kepada pegawainya. Dengan adanya motivasi dalam diri pegawai tentunya akan membuat mereka bekerja dengan serius, tekun, bergairah dan memiliki semangat kerja yang tinggi, ini akan berpengaruh terhadap hasil kerja. Hasil kerja yang baik akan mempengaruhi tingkat kepuasan kerja.

Aspek yang tak kalah pentingnya adalah sikap-sikap yang berhubungan dengan pekerja itu sendiri (work-releated attitudes) " work - releated attitudes" salah satunya adalah komitmen seorang karyawan terhadap organisasi yang mempekerjakannya. Yusuf dan Syarif (2018:32) mendefinisikan komitmen organisasi adalah sebagai sikap loyalitas karyawan 
terhadap organisasi, dengan cara tetap bertahan dalam organisasi, membantu mencapai tujuan organisasi dan tidak memiliki keinginanuntuk meninggalkan organisasi dengan alasan apapun. Pentingnya peran komitmen organisasi, sehingga beberapa organisasi berani memasukkan unsur komitmen sebagai salah satu syarat untuk memegang suatu jabatan atau posisi yang ditawarkan dalam iklan-iklan lowongan pekerjaan. Meskipun komitmen organisasi memegang peranan penting, namun tidak jarang pengusaha maupun pegawai masih belum memahami arti komitmen secara sungguh-sungguh. Padahal pemahaman tersebut sangatlah penting agar tercipta kondisi kerja yang kondusif, sehingga perusahaan dapat berjalan secara efisien dan efektif. Terciptanya kondisi kerja yang kondusif dan mampu menghasilkan kinerja yang efisien dan efektif dapat meningkatkan kepuasan kerja pegawai. Menurut Satria dalam Saputra dan Andri (2017) apabila komitmen organisasi semakin tinggi maka kepuasan kerja karyawan semakin tinggi, dan apabila komitmen organisasi semakin rendah maka semakin rendah pula kepuasan kerja karyawan. Keberhasilan dan prestasi yang dicapai organisasi perlu didukung sumber daya manusia yang berkualitas dengan komitmen yang tinggi. Davis dalam Saputra dan Andri (2017), mengungkapkan bahwa karyawan yang komitmen terhadap organisasi akan memperlihatkan rekaman kehadiran yang baik dan kemampuan untuk taat terhadap kebijakan organisasi dan tingkat turnover karyawan yang rendah

\section{KAJIAN TEORI}

Menurut Handoko (2014:193) kepuasan kerja adalah keadaan emosional yang menyenangkan atau tidak menyenangkan dari sudut pandang tenaga kerja atau karyawan yang memandang pekerjaan mereka. Hasibuan (2016:202) mendefinisikan kepuasan kerja sebagai bentuk sikap emosional yang menyenangkan maupun tidak menyenangkan. Karyawan yang puas akan pekerjaannya akan muncul dalam emosional karyawan. Kepuasan karyawan akan membuat para karyawan mencintai pekerjaannya. Kepuasan kerja dinikmati dalam pekerjaan, luar pekerjaan, dan kombinasi dari dalam dan dari luar pekerjaan.

Menurut Darmadi (2018: 125): "Motivasi adalah kekuatan, baik dari dalam maupun dari luar yang mendorong seseorang untuk mencpai tujuan tertentu yang telah ditetapkan sebelumnya". Gibson et al. (2011:52), menyatakan bahwa motivasi merupakan konsep yang digunakan untuk menggambarkan dorongan-dorongan yang timbul pada atau dalam diri seorang individu yang kemudian menggerakkan dan mengarahkan perilakunya.

Menurut Utaminingsih (2014:144): "Komtimen organisasi adalah keinginan para anggota organisasiuntuk tetap mempertahankan keanggotaannya dalam organisasi dan bersedia melakukan usaha yang tinggi bagi pencapaian tujuan organisasi". Menurut Darmadi (2018:201) menyatakan bahwa: "Komitmen organisasi merupakan kompetensi individu dalam mengikatkan dirinya terhadap nilai dan tujuan organisasi".

Menurut Sutrisno (2010:57) Lingkungan kerja adalah keseluruhan sarana dan prasarana kerja yang ada di sekitar pegawai yang sedang melakukan pekerjaan yang dapat mempengaruhi pelaksanaan pekerjaan. Menurut Veitzhal (2011:165) bahwa lingkungan kerja adalah keseluruhan sarana dan prasarana yang ada di sekitar karyawan yang sedang melakukan pekerjaan itu sendiri. Lingkungan kerja ini meliputi: tempat kerja, fasilitas dan alat bantu pekerjaan, kebersihan, pencahayaan, ketenangan termasuk juga hubungan antara orang-orang yang ada di tempat tersebut 


\section{Kaitan Antar Variabel}

\section{Pengaruh Lingkungan Kerja Terhadap Kepuasan Kerja}

Lingkungan kerja merupakan seluruh bentuk suasana disekitar para pekerja yang dapat mempengaruhi para pekerja dalam menjalankan tugas-tugas yang dibebankan kepadanya (Handoko, 2014:115). Setiap karyawan selalu mengharapkan lingkungan kerja yang akrab, nyaman dan saling mendukung. Dengan kata lain, lingkungan kerja diharapkan kondusif untuk menunjang kerja karyawan. Apabila karyawan merasa bahwa lingkungan fisik tempat bekerjanya baik akan memberikan kepuasan dan rasa bangga. Jika sarana dan prasarana yang menunjang pekerjaan tersedia, hal tersebut dapat menjadi kepuasan tersendiri bagi karyawan, dimana karyawan merasa diperhatikan oleh perusahaan. Selain lingkungan fisik, lingkungan non fisik juga memberikan kepuasan kerja karyawan, hal ini ditandai dengan terciptanya hubungan yang harmonis antara atasan dengan bawahan, rekan sekerja, dan bawahan di lingkungan kerja. Penelitian yang dilakukan oleh Saputra dan Andri (2017) menunjukkan bahwa lingkungan kerja terbukti berpengaruh positif dan signifikan terhadap kepuasan kerja. Hal ini sejalan dengan penelitian yang dilakukan oleh Husni, dkk (2018), menunjukkan bahwa lingkungan kerja berpengaruh signifikan terhadap kepuasan kerja. Oleh karena itu keadaan maupun situasi yang ada di sekitar karyawan dalam bekerja harus dijaga sebaik mungkin supaya karyawan akan merasa nyaman dalam bekerja.

\section{Pengaruh Motivasi terhadap Kepuasan Kerja}

Motivasi merupakan hal yang sangat diperlukan oleh setiap karyawan di dalam suatu perusahaan, sebab motivasi merupakan suatu dorongan yang ada dalam diri seseorang dalam usahanya memenuhi keinginan, maksud, dan tujuan. Pemberian motivasi dalam bekerja kepada karyawan adalah faktor yang penting dalam organisasi. Motivasi atau dorongan kepada karyawan akan meningkatkan semangat dalam melakukan pekerjaan sehingga dapat memperoleh output yang sesuai target perusahaan. Dengan didapatnya target yang tentukan, maka akan timbul rasa puas dalam diri karyawan

Penelitian Husni, dkk (2018) menyimpulkan bahwa motivasi berpengaruh terhadap kepuasan kerja karyawan. Dengan adanya motivasi dalam diri pegawai tentunya akan membuat mereka bekerja dengan serius, tekun, bergairah dan memiliki semangat kerja yang tinggi yang nantinya akan berpengaruh terhadap hasil kerja. Hasil kerja yang melampuai target akan mempengaruhi tingkat kepuasan kerja. Kemudian Darmawan (2016) juga melakukan penelitian mengenai pengaruh motivasi terhadap kepuasan kerja. Hasil penelitiannya menunjukkan bahwa motivasi berpengaruh terhadap kepuasan kerja karyawan. Artinya semakin baik motivasi yang diberikan kepada pegawai maka kepuasan kerja pegawai akan semakin meningkat.

\section{Pengaruh Komitmen Organisasi terhadap Kepuasan Kerja}

Komitmen organisasional merupakan suatu keadaan yang menunjukkan adanya keterikatan psikologis seorang pegawai pada suatu organisasi untuk loyal dan terlibat dalam organisasi. Semakin loyal seorang pegawai maka semakin tinggi pula komitmen organisasionalnya. Iswanda (2017) dalam penelitiannya menyatakan bahwa komitmen organisasi berpengaruh signifikan terhadap kepuasan kerja karyawan. Semakin tinggi komitmen karyawan terhadap organisasi menunjukkan adanya kepuasan karyawan dalam bekerja

Penelitian Saputra dan Andri (2017) mengungkapkan bahwa komitmen organisasi mempengaruhi kepuasan kerja karyawan. Darmawan (2016) juga menyatakan bahwa komitmen organisasi berpengaruh positif terhadap kepuasan kerja karyawan. Komitmen akan mencerminkan tingkat kesungguhan pegawai dalam menjalankan tugas dan fungsinya. Sebab 
adanya komitmen yang tinggi akan memberikan pengaruh positif terhadap kepuasan kerja pegawai

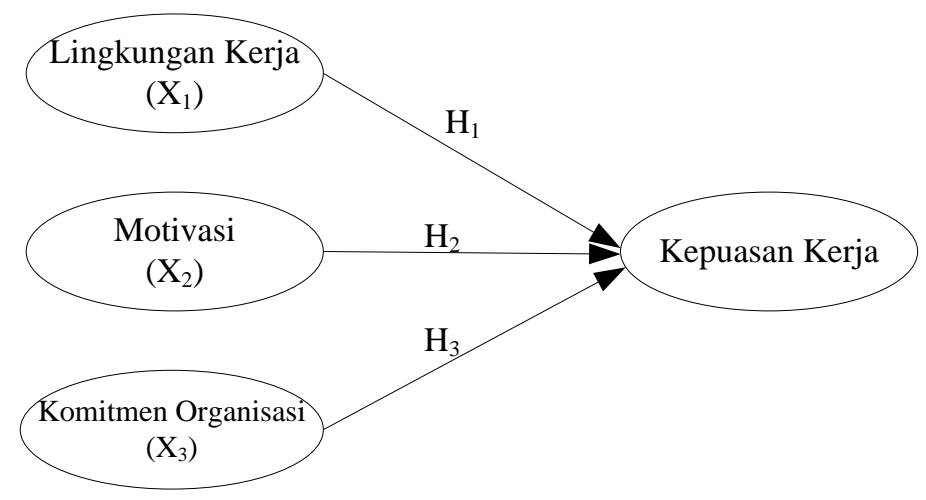

Gambar 1. Kerangka Pemikiran

Berdasarkan kerangka pemikiran diatas maka hipotesis penelitian ini adalah sebagai berikut:

$\mathrm{H}_{1}$ : Terdapat pengaruh signifikan Lingkungan kerja terhadap kepuasan kerja karyawan

$\mathrm{H}_{2}$ : Terdapat pengaruh signifikan motivasi terhadap kepuasan kerja karyawan

$\mathrm{H}_{3}$ : Terdapat pengaruh signifikan komitmen terhadap kepuasan kerja karyawan

\section{METODE PENELITIAN}

Disain penelitian terdiri atas disain penelitian eksploratif dan konklusif (Soegoto, 2009:36). Disain penelitian konklusif terdiri atas disain penelitian deskriptif dan kausal. Disain penelitian deskriptif digunakan untuk menguji hipotesis yang tidak bersifat kausal, tidak ada variabel yang dimanipulasi atau yang lazim disebut sebagai variabel perlakuan. Disain penelitian kausal sering juga disebut sebagai disain penelitian eksperimental. Penelitian ini menggunakan disain penelitian deskriptif yang bertujuan membuat deskriptif secara sistematis, faktual, dan akurat mengenai fakta-fakta dan sifat-sifat dari populasi. Populasi dalam penelitian ini adalah seluruh karyawan PT. Pilar Logam Perkasa sebanyak 95 karyawan. Jumlah sampel sebanyak 76 responden

Data dianalisis menggunakan PLS-SEM dimana data diolah dengan program software SmartPLS 3. Pertama, pengolahan dilakukan pada outer model untuk menguji validitas (konvergen dan diskriminan) dan reliabilitas. Uji validitas konvergen dilihat dari nilai outer loadings di antara 0,5-0,7 kemudian AVE > 0,5. Selanjutnya untuk uji validitas diskriminan, beracuan pada Fornell-Larcker Criterion dan Cross Loadings (Garson, 2016). Kemudian pada analisis reliabilitas, beracuan pada nilai cronbach's alpha dan composite reliability > 0,7 (Ghozali dan Latan, 2015:75).

Kedua, pengolahan dilakukan pada inner model untuk menguji hipotesis yang telah dihasilkan. Sebelum pengujian hipotesis, pertama dilakukan pengujian hubungan antar konstruk dengan melihat nilai R-square $\left(\mathrm{R}^{2}\right)$ dengan kriteria $(1-0,75)$ "bersifat kuat", $(0,74$ - 0,5) "bersifat moderat", dan $(0,49$ - 0,25) "bersifat lemah" (Ghozali dan Latan, 2015:78), nilai $\mathrm{Q}$-square $\left(\mathrm{Q}^{2}\right)$ dengan kriteria $\mathrm{Q}^{2}>0$ "memiliki kemampuan prediksi" (Chin, 2010), dan nilai GoF (Goodness of Fit) dengan kriteria 0,1 "kelayakan model kecil", 0,25 "kelayakan model sedang", dan 0,36 "kelayakan model besar" (Tenenhaus, 2005). Selanjutnya pengujian hipotesis, untuk melihat pengaruh yang terjadi lihat (positif/ negatif) dari coefficient yang dihasilkan, dan menggunakan $t$-statistics $>1,645$ (hipotesis tidak ditolak) dan $p$-values $<0,05$ (hipotesis signifikan) (Haryono, 2017:40). 


\section{HASIL UJI STATISTIK}

\section{Hasil Uji validitas}

Pada hasil validitas konvergen, didapatkan semua angka $>0,5$ pada nilai outer loadings untuk setiap pernyataannya, dan didapatkan semua angka $>0,5$ pada nilai Average Variance Extracted / AVE maka pernyataan yang digunakan sudah valid secara validitas konvergen. Selain itu, pada hasil validitas diskriminan, peneliti menggunakan nilai Cross Loadings dimana nilai korelasi antara pernyataan terhadap variabel nya sendiri harus lebih besar daripada pernyataan terhadap variabel lainnya berdasarkan hasil kalkulasi SmartPLS 3, didapatkan semua angka pada pernyataan terhadap variabel-nya sendiri lebih besar daripada terhadap variabel lainnya maka pernyataan sudah valid secara validitas diskriminan.

\section{Hasil Uji reliabilitas}

Pada hasil reliabilitas, maka berdasarkan hasil yang dikalkulasi oleh program SmartPLS 3, didapatkan semua angka pada nilai Cronbach's Alpha untuk setiap pernyataannya adalah > 0,7 dan pada nilai Composite Reliability didapatkan semua angka untuk setiap pernyataannya adalah $>0,7$. Maka pernyataan yang digunakan dalam penelitian ini sudah reliabel berdasarkan kedua nilai reliabilitas, yakni Cronbach's Alpha dan Composite Reliability.

\section{Hasil Uji R-Square $\left(\mathbf{R}^{2}\right)$ dan GoF (Goodness of Fit)}

Dapat diketahui nilai $R$-Square untuk variabel kepuasan kerja adalah 0,746. Perolehan nilai tersebut menjelaskan bahwa presentase besarnya kepuasan kerja dapat dijelaskan oleh lingkungan kerja, motivasi dan komitmen organisasi sebesar 74,6\%. Sedangkan sisanya sebesar 25,4\% dipengaruhi oleh faktor lain.

Hasil uji GoF, didapatkan nilai GoF sebesar 0,557 yang berarti bahwa keseluruhan dalam kinerja model prediksi yang ditinjau pada tingkat kesesuaian antara inner model dengan outer model adalah besar karena di atas 0,36.

\section{Hasil Uji Hipotesis}

Tabel 1

Hasil Uji Hipotesis (Bootstrapping)

\begin{tabular}{|l|l|l|l|l|l|}
\hline & $\begin{array}{c}\text { Original } \\
\text { Sample (O) }\end{array}$ & $\begin{array}{c}\text { Sample } \\
\text { Mean (M) }\end{array}$ & $\begin{array}{c}\text { Standar } \\
\text { Deviation } \\
\text { (STDEV) }\end{array}$ & $\begin{array}{c}\text { T Statistics } \\
\text { (JO/STDEV) }\end{array}$ & $\begin{array}{c}\text { P } \\
\text { Value }\end{array}$ \\
\hline $\begin{array}{l}\text { Lingkungan Kerja } \rightarrow \\
\text { Kepuasan kerja }\end{array}$ & 0.254 & 0.254 & 0.084 & 3.000 & 0.003 \\
\hline Motivasi $\rightarrow$ Kepuasan kerja & 0.476 & 0.476 & 0.098 & 4.879 & 0.000 \\
\hline $\begin{array}{l}\text { Komitmen Organisasi } \rightarrow \\
\text { Kepuasan kerja }\end{array}$ & 0.279 & 0.284 & 0.093 & 2.984 & 0.003 \\
\hline
\end{tabular}

Sumber: Hasil Olah Data pada SmartPLS3 


\section{DISKUSI}

Hipotesis yang pertama menunjukkan bahwa variabel lingkungan kerja terbukti berpengaruh secara signifikan terhadap kepuasan kerja karyawan karena hasil dari nilai tstatistik lingkungan kerja sebesar 3,000 yang berarti lebih besar dari 1,96 dan p-values lingkungan kerja sebesar 0,003 yang berarti lebih kecil dari 0,05. Sehingga dapat disimpulkan bahwa lingkungan kerja memiliki pengaruh yang signifikan terhadap kepuasan kerja karyawan. Hal tersebut sesuai dengan penelitian yang telah dilakukan Saputra dan Andri (2017) serta Husni, dkk (2018), yang menunjukkan bahwa lingkungan kerja berpengaruh signifikan terhadap kepuasan kerja. Lingkungan kerja merupakan seluruh bentuk suasana disekitar para pekerja yang dapat mempengaruhi para pekerja dalam menjalankan tugas-tugas yang dibebankan kepadanya. Setiap karyawan selalu mengharapkan lingkungan kerja yang akrab, nyaman dan saling mendukung. Dengan kata lain, lingkungan kerja diharapkan kondusif untuk menunjang kerja karyawan. Apabila karyawan merasa bahwa lingkungan fisik tempat bekerjanya baik akan memberikan kepuasan dan rasa bangga. Jika sarana dan prasarana yang menunjang pekerjaan tersedia, hal tersebut dapat menjadi kepuasan tersendiri bagi karyawan, dimana karyawan merasa diperhatikan oleh perusahaan. Selain lingkungan fisik, lingkungan non fisik juga memberikan kepuasan kerja karyawan.

Kemudian untuk hipotesis kedua dapat disimpulkan motivasi memiliki pengaruh yang signifikan terhadap kepuasan kerja karyawan dengan tingkat keyakinan 95\%. Hasil nilai tstatistik motivasi sebesar 4,879yang berarti lebih besar dari 1,96 dan p-values motivasi sebesar 0,000 yang berarti lebih kecil dari 0,05. Sehingga dapat disimpulkan bahwa motivasi memiliki pengaruh yang signifikan terhadap kepuasan kerja karyawan. Hasil penelitian ini sejalan dengan penelitian Husni, dkk (2018) dan Darmawan (2016) yang menyimpulkan bahwa motivasi berpengaruh terhadap kepuasan kerja. Motivasi atau dorongan kepada karyawan akan meningkatkan semangat dalam melakukan pekerjaan sehingga dapat memperoleh output yang sesuai target perusahaan. Dengan didapatnya target yang tentukan, maka akan timbul rasa puas dalam diri karyawan.

Untuk hipotesis ketiga, dapat disimpulkan komitmen organisasi memiliki pengaruh yang signifikan terhadap kepuasan kerja karyawan dengan tingkat keyakinan 95\%. Hasil penelitian ini sejalan dengan penelitian Iswanda (2017) , Saputra dan Andri (2017) dan Darmawan (2016) yang menyimpulkan bahwa komitmen organisasi berpengaruh terhadap kepuasan kerja. Komitmen organisasi merupakan suatu keadaan yang menunjukkan adanya keterikatan psikologis seorang pegawai pada suatu organisasi untuk loyal dan terlibat dalam organisasi. Semakin loyal seorang pegawai maka semakin tinggi pula komitmen organisasinya. Semakin tinggi komitmen karyawan terhadap organisasi menunjukkan adanya kepuasan karyawan dalam bekerja. Komitmen akan mencerminkan tingkat kesungguhan pegawai dalam menjalankan tugas dan fungsinya. Sebab dengan adanya komitmen yang tinggi akan memberikan pengaruh positif terhadap kepuasan kerja pegawai.

\section{PENUTUP}

Berdasarkan penelitian dan pembahasan, maka dapat diambil beberapa kesimpulan sebagai berikut:

1. Terdapat pengaruh yang signifikan antara lingkungan kerja terhadap kepuasan kerja karyawan PT Citra Crocotama International. Artinya, semakin baik lingkungan kerja maka kepuasan kerja pegawai akan semakin tinggi, sebaliknya semakin tidak baik lingkungan kerja maka kepuasan kerja pegawai akan semakin rendah

2. Terdapat pengaruh yang signifikan antara motivasi terhadap kepuasan kerja kinerja karyawan PT Citra Crocotama International. Motivasi adalah proses yang menjelaskan 
intensitas, arah, dan ketekunan usaha individu ke arah pencapaian sasaran. Motivasi dapat meningkatkan kepuasan kerja karyawan. Semakin baik Motivasi yang diberikan oleh perusahaan maka akan semakin meningkatkan kepuasan kerja pada diri setiap karyawan.

3. Terdapat pengaruh yang signifikan antara komitmen organisasi terhadap kepuasan kerja karyawan PT Citra Crocotama International. Apabila komitmen organisasi semakin tinggi maka kepuasan kerja karyawan semakin tinggi, dan apabila komitmen organisasi semakin rendah maka semakin rendah pula kepuasan kerja karyawan.

Setelah meneliti dan mengetahui permasalahan yang ada di PT Citra Crocotama International, maka saran yang dapat diberikan bagi perusahaan dan bagi peneliti lain yaitu:

1. Bagi perusahaan. Dalam hal ini, penulis menyarankan bahwa pimpinan PT Citra Crocotama International sebaiknya dapat memperhatikan dan menunjang peningkatan kepuasan kerja karyawannya agar dapat meningkat dan menjadi lebih baik dengan cara menciptakan lingkungan pekerjaan yang nyaman dan aman. Dengan lingkungan kerja yang nyaman akan membuat karyawan memiliki semangat kerja yang tinggi yang pada akhirnya akan meningkatkan rasa puas dari karyawan.

2. Perusahaan dapat meningkatkan kepuasan kerja dengan cara mengusahakan motivasi kerja yang baik. Perusahaan sebaiknya lebih memperhatikan prasarana atau fasilitas pendukung di tempat kerja, karena hal tersebut merupakan indikator yang paling rendah pengaruhnya terhadap kepuasan kerja karyawan. Selain itu perusahaan juga dapat motivasi dengan memberikan insentif dan penghargaan. Insentif dan penghargaan yang diberikan dapat meningkatkan motivasi karyawan dan meningkatkan kepuasan kerja karyawan.

3. Peningkatan kepuasan kerja juga dapat dilakukan dengan cara meningkatkan komitmen organisasional. Perusahaan Perusahaan dapat meningkatkan komitmen karyawan dengan memmenuhi kebutuhan karyawan dengan terpenuhinya kebutuhan karyawan, maka karyawan akan merasa diperhatikan dan akan menimbulkan rasa memiliki terhadap perusahaan sehingga akan meningkatkan komitmen karyawan terhadap perusahaan. Apabila komitmen organisasi semakin tinggi maka kepuasan kerja karyawan semakin tinggi, dan apabila komitmen organisasi semakin rendah maka semakin rendah pula kepuasan kerja karyawan.

4. Bagi peneliti lain, disarankan untuk melakukan penambahan variabel lain yang juga diperkirakan dapat memberikan pengaruh terhadap kepuasan kerja karyawan seperti budaya organisasi, dan kompensasi.

\section{DAFTAR PUSTAKA}

Darmadi (2018) Manajemen Sumber Daya Manusia. Yogyakarta: Budi Utama

Darmawan, Didit (2016) Peranan Motivasi Kerja, Komitmen Organisasi Dan Budaya Organisasi Terhadap Kepuasan Kerja. Jurnal Ilmiah Manajemen Pendidikan Indonesia. Vol. 2, No. 3 :97-106

Ghozali, Imam (2014) Structural Equation Modeling - Metode Alternatif dengan Partial Least Squares (PLS). Semarang: Badan Penerbit Universitas Diponegoro

Gibson, James L., Donnelly Jr, James H., Ivancevich, John M., Konopaske, Robert (2011). Organizationa Behavior, Structure, Processes, Fourteenth Edition (International Edition). New York: McGraw-Hill.

Hair, J. F., Ringle, C. M., \& Sarstedt, M. (2011). PLS-SEM:Indeed a Silver Bullet. Journal of Marketing theory and Practice, 19(2): 139-152.

Hamid Sanusi (2014) Manajemen Sumber Daya Manusia Lanjutan. Yogyakarta: Budi Utama 
Handoko, T.Hani. (2014). Manajemen Personalia dan Sumber Daya Manusia. Edisi II. Yogyakarta: BPFE Jogjakarta.

Hariandja, Tua Efendi (2007) Manajemen Sumber Daya Manusia. Jakarta: Grasindo Husni, Said Musnadi dan Faisal (2018) Pengaruh Lingkungan Kerja, Kompensasi Dan Motivasi Terhadap Kepuasan Kerja Serta Dampaknya Terhadap Loyalitas Kerja Pegawai Rutan Di Provinsi Aceh (Studi Kasus Pada Rutan Klas Iib Banda Aceh Dan Rutan Klas Ii B Jantho. Jurnal Magister Manajemen. Vol. 2 No. 1 :88-98

Saputra, Apandi dan Andri, Seno (2017) Pengaruh Lingkungan Kerja Dan Komitmen Organisasi Terhadap Kepuasan Kerja Karyawan (Studi Kasus Pada Hotel Ratu Mayang Garden Pekanbaru). JOM FISIP. Vol.4 No.2:1-15

Soegoto, Eddy Soeryanto. (2009). Marketing Research. Jakarta: Elex Media Computindo

Sutrisno, Edy (2017). Sumber Daya Manusia. Jakarta: Kencana

Timotius Duha (2016) Perilaku Organisasi. Yogyakarta: Budi Utama

Utaminingsih, Alifiulahtin (2014) Perilaku Organisasi: Kajian Teoritik dan Empirik Terhadap Budaya Organisasi, Gaya Kepemimpinan, kepercayaan dan komitmen. Malang: UB Press.

Veithzal, Rivai. (2011). Manajemen Sumber Daya Manusia untuk Perusahaan: dari Teori Ke Praktik. Jakarta: Raja Grafindo Persada

Wuwungan, Ronna Yulia, Rita N. Taroreh dan Yantje Uhing (2017) Pengaruh Lingkungan Kerja Dan Motivasi Kerja Terhadap Kepuasan Kerja Karyawan Cinema XX Lippo Plaza Manado. Jurnal EMBA. Vol.5 No.2 : 298 - 307

Yusuf, Ria Mardiana dan Syarif Darman (2018) Komitmen Organisasi: Definisi, Pengaruh, Mempengaruhi. Makasar: Nas Media Pustaka 